\title{
Seroprevalence of HIV Infection and Associated Factors Among Newly Incarcerated Prisoners in Abidjan, Ivory Coast
}

\author{
Aké-Tano Sassor Odile Purifine ${ }^{1,2, *}$, Konan Yao Eugène ${ }^{1,2}$, Kpebo Djoukou Olga Denise ${ }^{1,2}$, \\ Tetchi Ekissi Orsot ${ }^{1,2}$, Douba Alfred ${ }^{1,3}$, Sablé Stéphane Parfait ${ }^{1,2}$, Ekou Franck Kokora ${ }^{1,2}$, \\ Kouassi Ange Boris ${ }^{1}$, Dagnan N'Cho Simplice ${ }^{1,3}$ \\ ${ }^{1}$ National Institute of Public Health, Abidjan, Ivory Coast \\ ${ }^{2}$ Public Health and Biostatistics Department, Training and Research Unit of Medical School, University Félix Houphouet Boigny, Abidjan, \\ Ivory Coast \\ ${ }^{3}$ National Institute of Public Hygiene, Abidjan, Ivory Coast
}

Email address:

odileake@yahoo.fr (Aké-Tano. S. O. P.)

${ }^{*}$ Corresponding author

\section{To cite this article:}

Aké-Tano Sassor Odile Purifine, Konan Yao Eugène, Kpebo Djoukou Olga Denise, Tetchi Ekissi Orsot, Douba Alfred, Sablé Parfait Sable, Ekou Franck Kokora, Kouassi Ange Boris, Dagnan N'Cho Simplice. Seroprevalence of HIV Infection and Associated Factors Among Newly Incarcerated Prisoners in Abidjan, Ivory Coast. Science Journal of Public Health. Vol. 5, No. 5, 2017, pp. 377-382. doi: $10.11648 /$ j.sjph.20170505.13

Received: June 28, 2017; Accepted: July 13, 2017; Published: August 7, 2017

\begin{abstract}
Poor socio-economic condition of prisoners and practices at risk of getting transmissible diseases in most prisons contribute to the spread of Human Immunodeficiency Virus (HIV) infection. The objectives of this study were to determine HIV seroprevalence among newly incarcerated persons, to describe their risk behaviors, and to identify factors associated with HIV infection. We conducted a cross-sectional study from January 2014 to February 2014 at the biggest prison of Abidjan called "House of Judgement and Correction of Abidjan" (HJCA). Study population included newly incarcerated persons aged more than 18 years. Overall, 370 people were included after an informed consent. Findings showed that $13 \%$ of inmates used drug; $8.3 \%$ of them using injectable drugs. The vast majority of respondents $(97.3 \%)$ experienced sexual intercourse and $31.9 \%$ had multiple sexual partners. More than half $(50.6 \%)$ of respondents did not use condom, and among those who use it, $73.6 \%$ used it irregularly. During their last sexual intercourse, $71.8 \%$ of respondents did not use condom. Overall, $7.9 \%$ of respondents were HIV positive. Factors associated with HIV positive status were history of herpes zoster (adj. OR=16.66, 95\% CI: 2.66-104.08, $\mathrm{p}=0.003$ ), history of STIs (adj. OR=8.82, 95\% CI: 3.25-23.95, $\mathrm{p}<0.001$ ), history of tuberculosis (adj. $\mathrm{OR}=6.49,95 \%$ CI: $1.06-39.79, \mathrm{p}=0.043$ ), and having had more than one sexual partner over the last 12 months (adj. OR=8.11, 95\% CI: 1.75-37.51, $\mathrm{p}=0.007$ ). Promoting safer behaviors, routine HIV screening among prisoners, care for HIV-positive people, and improved living conditions in prisons are needed measures to control HIV / AIDS in prison environment in Ivory Coast.
\end{abstract}

Keywords: Prison Environment, HIV/AIDS, Associated Factors, Ivory Coast

\section{Introduction}

In many countries, HIV infection is a serious health problem for prison populations and a major challenge for prison services, public health services and governments. The generally accepted principle that prisons and detainees are part of the wider community means that the threat posed by HIV to prisons also has an impact outside the prisons and therefore calls for some coordinated action [1]. Prisons around the world are being seriously hit by the HIV 
epidemic. HIV infection rates and the number of confirmed AIDS cases are very high in prisons. Indeed, HIV prevalence is 4 to 50 times higher among inmates than in adult population out of prisons [2]. Given the unhealthy environment in most prisons, which contributes to the spread of many infectious diseases including HIV, it seems important to know HIV status and risk behaviors of prisoners upon admission in order to identify and implement appropriate strategies to effectively control this scourge in prisons.

In Ivory Coast, living conditions in prisons are very difficult. Indeed, there is a strong promiscuity with recurrent sexual violence, precarious hygiene and undernourishment [3]. Several epidemics occurred in prisons, including cholera epidemic, shigellosis epidemic and the beriberi epidemic which occurred in 2002 and 2003 at Abidjan main prison, called "House of Judgement and Correction of Abidjan" (HJCA). These outbreaks are the consequence of the poor living conditions in this prison.

Very few studies about Sexually Transmitted Infections (STIs) including HIV have been conducted in prisons in Ivory Coast. Therefore, we conducted this study about HIV seroprevalence among new detainees at the HJCA. The purpose of this study is to contribute to HIV control in prisons in Ivory Coast. The objectives of this study were to determine the HIV seroprevalence among new detainees, to describe their behaviors at risk of getting HIV infection, and to identify the factors associated with HIV infection among new prisoners.

\section{Methodology}

\subsection{Study Site}

It was a cross-sectional study conducted at the HJCA, the main prison of Abidjan. This prison has been built in 1970 and is the biggest and main prison in Ivory Coast. In 2010, 5 300 people were detained at the HJCA which was built to accommodate 1500 individuals. The monthly number of incarcerated people and released individuals is estimated to 600. In order to provide medical care to detainees, the prison clinic works in collaboration with a Non-Governmental Organization (NGO) called "Ensemble pour une Solidarité Thérapeutique Hospitalière en Réseau" (ESTHER). ESTHER is a French public organization involved in capacity building, in care and treatment for HIV/AIDS patients in 18 countries.

At the prison clinic, any new detainee goes through HIV counseling and then a HIV test is proposed to this new detainee. Most of the time, more than three quarters of new prisoners accept the proposed HIV test.

\subsection{Type of Study}

It was a cross sectional study, conducted during a period of 2 months, from January to February 2014.

\subsection{Study Population}

This study included new detainees aged more than 18, with HIV-positive test, who gave their consent to participate in the study. Eligible individuals were included in the study upon their arrival at the entrance of the HJCA.

\subsection{Study Sample}

Study sample has been determined using the following formula:

$$
\mathrm{n}=\mathrm{c} \times \frac{\varepsilon_{\alpha}^{2}}{\mathrm{i}^{2}} \times \mathrm{p}(1-\mathrm{p})
$$

c: corrector coefficient $=4$

$\varepsilon_{\alpha}$ : is the standard normal variate at the risk $\alpha$ (type 1 error) of $5 \%=1.96$

i: precision of the estimate $=0.05$

p: HIV prevalence among new detainees at HJCA from November 2008 to March $2010=5.4 \%$ [3]

$$
\mathrm{q}=1-\mathrm{p}
$$

Overall, 370 people were included in this study.

\subsection{Data Collection}

Data were collected using a questionnaire during a face-toface interview. Upon arrival at the HJCA, all new prisoners attended HIV counselling session. Questionnaire was only administered to individuals who accepted HIV test after the counselling session. Variables included in the questionnaire were grouped into four categories.

a. Category 1 refers to "sociodemographic characteristics" including age, sex, education level, marital status, citizenship, and number of incarceration.

b. Category 2 refers to "sexual and other behaviour at risk of getting HIV" including drug consumption, method of drug consumption, number of sexual partners over the last twelve months, type of sexual partners, sexual intercourse with prostitutes, condom use during sexual intercourses, and frequency of condom use.

c. Category 3 refers to "medical history" included STIs, herpes zoster, and tuberculosis.

d. Category 4 refers to "HIV status" included HIVpositive, and HIV-negative.

\subsection{Data Analysis}

Data were analysed using Epi-info 3.5.1 and SPSS 16. Dependent variable was "HIV status". Independent variables included age, sex, education level, marital status, citizenship, number of incarceration, drug consumption, method of drug consumption, number of sexual partners over the last twelve months, type of sexual partners, sexual intercourse with prostitutes, condom use during sexual intercourses, frequency of condom use, history of STIs, history of herpes zoster, and history of tuberculosis.

For quantitative variables, means and standard deviation were computed; for qualitative variables, proportions were 
computed.

Univariate analysis was run using Chi square test in order to determine a link between the dependent variable and independent variables. In addition, multivariate analysis was run using Fisher method in order to identify factors associated with HIV-positive status. The measure of association was the adjusted Odds Ratio (adj. OR) with 95\% confident interval $(95 \% \mathrm{CI})$.

\subsection{Ethical Considerations}

Prior to the beginning of the study, agreements were obtained both from the director of Eastern Yopougon health district and from the director of the HJCA, this prison being included in the health district of Eastern Yopougon. Verbal informed consent was also obtained from each participant of the study. The anonymity of respondents was respected.

\section{Results}

\subsection{Sociodemographic Characteristics of Respondents}

Sociodemographic characteristics of 370 respondents are presented in table 1 . The mean age of respondents was 30 years and the standard deviation was 8.6 years. The vast majority of respondents aged 20 to 39 years; $79.7 \%$ of them were singles, and $75.6 \%$ of them were males. Overall, $35.9 \%$ of respondents were unschooled and $96.2 \%$ of them were at their first incarceration.

Table 1. Distribution of detainees by sociodemographic characteristics, HJCA, 2014.

\begin{tabular}{lll}
\hline Sociodemographic characteristics & Number & Percentage \\
\hline Age (years) & & \\
$<20$ & 21 & 5.6 \\
$20-29$ & 178 & 48.1 \\
$30-39$ & 127 & 34.3 \\
$40-49$ & 32 & 8.6 \\
$\geq 50$ & 12 & 3.2 \\
Sex & & \\
Male & 280 & 75.6 \\
Female & 90 & 24.3 \\
Citizenship & & \\
Ivorian & 288 & 77.8 \\
Non-ivorian & 82 & 22.2 \\
Education & & \\
Unschooled & 133 & 35.9 \\
Primary & 79 & 21.3 \\
Secondary & 129 & 34.9 \\
High & 29 & 7.8 \\
Marital status & & \\
Married & 75 & 20.3 \\
Single & 295 & 79.7 \\
Number of incarcerations & & \\
1 & 356 & 96.2 \\
$>1$ & 14 & 3.8 \\
\hline
\end{tabular}

\subsection{Behaviour at Risk of Getting HIV and Medical History}

Overall, 13\% of respondents were drug consumers and 8.3 of them used injectable drugs. The vast majority of study participants $(97.3 \%)$ had experienced sexual intercourse and $99.7 \%$ were heterosexuals. Over the last twelve months before the survey, $31.9 \%$ of detainees had had more than one sexual partner and $50.6 \%$ did not use condom. Among respondents who used condom, 73.6\% used it irregularly. During their last sexual intercourse, $71.8 \%$ of respondents did not use condom as shown in table 2. Overall, $22.2 \%, 2.2 \%$ and $3 \%$ of respondents had history of STIs, herpes zoster and tuberculosis respectively.

Table 2. Distribution of detainees by Sexual behavior, HJCA, 2014.

\begin{tabular}{lll}
\hline Sexuality and use of condoms & Number & Percentage \\
\hline $\begin{array}{l}\text { Number of sexual partners over the last 12 } \\
\text { months }\end{array}$ & & \\
No & 15 & 4.2 \\
One & 230 & 63.9 \\
Two and more & 115 & 31.9 \\
Type of sexual partner & & \\
Regular & 254 & 70.6 \\
Occasional & 18 & 5 \\
Regular and occasional & 88 & 24.4 \\
Sexual relations with sex workers & & \\
Yes & 21 & 5.8 \\
No & 339 & 94.2 \\
Condom use during sexual intercourse & & \\
Yes & 178 & 49.4 \\
No & 182 & 50.6 \\
Condom use & & \\
Regular & 47 & 26.4 \\
Irregular & 131 & 73.6 \\
Condom use during the last sexual intercourse & 52 & 29.2 \\
Yes & 126 & 71.8 \\
No & & \\
\hline
\end{tabular}

\subsection{HIV Status}

More than half of respondents (58.1\%) did not know their HIV status before incarceration. Overall, $7.9 \%$ of study participants were HIV-positive and $96.6 \%$ of them had type 2 HIV.

\subsection{Factors Associated with HIV-positive Status}

Proportion of HIV-positive respondents was higher among those aged 30 years and greater compared to participants less than 30 years $(p=0.01)$. Proportion of HIV-positive was also higher among married compared to single respondents $(p=0.04)$. Proportion of HIV-positive was high among respondents with history of STIs $(p<0.001)$, herpes zoster $(p=0.001)$, and tuberculosis $(\mathrm{p}=0.007)$. HIV infection was prevalent among respondents who had had more than one sexual partner over the last twelve months before the survey compared to those who did not $(\mathrm{p}<0.001)$. HIV infection was also 
common among study participants who had occasional sexual partners compared to those who had a regular sexual partner $(\mathrm{p}<0.001)$ as shown in table 3 .

Table 3. Distribution of HIV status by detainees' characteristics, HJCA, 2014.

\begin{tabular}{|c|c|c|c|}
\hline & \multicolumn{2}{|c|}{ HIV status } & \multirow{3}{*}{ p value } \\
\hline & \multirow{2}{*}{$\begin{array}{l}\text { Positive } \\
\text { n (\%) } \\
\end{array}$} & \multirow{2}{*}{$\begin{array}{l}\text { Negative } \\
\text { n (\%) }\end{array}$} & \\
\hline & & & \\
\hline \multicolumn{4}{|c|}{ Sociodemographic characteristics } \\
\hline \multicolumn{4}{|c|}{ Age (Years) } \\
\hline$<30$ & $9(4.5)$ & $190(95.5)$ & \multirow{2}{*}{0.0104} \\
\hline$\geq 30$ & $20(11.7)$ & $151(83.3)$ & \\
\hline \multicolumn{4}{|l|}{$\operatorname{Sex}$} \\
\hline Male & $20(7.1)$ & $260(92.9)$ & \multirow{2}{*}{0.3803} \\
\hline Female & $9(10.0)$ & $81(90.0)$ & \\
\hline \multicolumn{4}{|c|}{ Marital status } \\
\hline Married & $10(13.3)$ & $65(86.7)$ & \multirow{2}{*}{0.047} \\
\hline Single & $19(6.4)$ & $276(93.6)$ & \\
\hline \multicolumn{4}{|l|}{ Citizenship } \\
\hline Ivorian & $25(8.6)$ & $263(91.4)$ & \multirow{2}{*}{0.2583} \\
\hline Non-ivorian & $4(4.8)$ & $78(95.2)$ & \\
\hline \multicolumn{4}{|c|}{ Instruction level } \\
\hline Uneducated & $11(8.3)$ & $122(91.7)$ & \multirow{2}{*}{0.8164} \\
\hline Educated & $18(7.6)$ & $219(92.4)$ & \\
\hline \multicolumn{4}{|l|}{ History } \\
\hline \multicolumn{4}{|l|}{$I S T$} \\
\hline Yes & $21(26.5)$ & $58(73.5)$ & \multirow{2}{*}{$<0.001$} \\
\hline No & $8(2.7)$ & $283(97.3)$ & \\
\hline \multicolumn{4}{|c|}{ Herpes Zoster } \\
\hline Yes & $5(62.5)$ & $3(37.5)$ & \multirow{2}{*}{$<0.001$} \\
\hline No & $24(6.7)$ & $338(93.3)$ & \\
\hline \multicolumn{4}{|l|}{ Tuberculosis } \\
\hline Yes & $4(36.3)$ & $7(63.7)$ & \multirow{2}{*}{0.007} \\
\hline No & $25(6.9)$ & $334(93.1)$ & \\
\hline \multicolumn{4}{|c|}{ Sexual partners } \\
\hline \multicolumn{4}{|c|}{ Type of sexual partners } \\
\hline Regular & $10(3.9)$ & $244(96.1)$ & \multirow{2}{*}{$<0.001$} \\
\hline Occasional & $19(11.1)$ & $87(88.8)$ & \\
\hline \multicolumn{4}{|c|}{$\begin{array}{l}\text { Number of sexual partners over } \\
\text { the past } 12 \text { months }\end{array}$} \\
\hline $0-1$ & $6(2.5)$ & $239(97.5)$ & \multirow{2}{*}{$<0.001$} \\
\hline$>1$ & $23(18.4)$ & $102(81.6)$ & \\
\hline \multicolumn{4}{|c|}{$\begin{array}{l}\text { Sexual intercourse with sex } \\
\text { workers }\end{array}$} \\
\hline Yes & $2(9.5)$ & $19(90.4)$ & 07088 \\
\hline No & $27(7.9)$ & $312(92)$ & 0.1988 \\
\hline
\end{tabular}

In multivariate analysis, age (adj. OR $=1.41,95 \% \mathrm{CI}$ : 0.48-4.14), marital status (adj. OR=1.94, 95\% CI: $0.63-$ 6.01 ), and the type of sexual partners (adj. OR=0.82, 95\% CI: 0.20-3.29) were not associated with HIV status. However, history of herpes zoster (adj. OR $=16.66,95 \% \mathrm{CI}$ : 2.66-104.08), history of STIs (adj. OR=8.82, 95\% CI: 3.25 23.95 ), and history of tuberculosis (adj. $\mathrm{OR}=6.49,95 \% \mathrm{CI}$ : 1.06-39.79) were associated with HIV status. In addition, respondents who had had more than one sexual partner over the last twelve months before the survey had 8 times more risk of getting HIV infection compared to those who had only one sexual partner $(\operatorname{adj} . \mathrm{OR}=8.11,95 \% \mathrm{CI}: 1.75-37.51)$ as shown in table 4 .

Table 4. Factors associated with HIV-positive status among new detainees ( $n=360,29$ new detainees were VIH-positive).

\begin{tabular}{llll}
\hline Variables & Adj. OR & $\mathbf{9 5 \%}$ CI & p \\
\hline History of STIs & & & \\
Yes & 8.826 & $3.251-23.958$ & $<0.001$ \\
No & 1 & - & \\
History of Herpes zoster & & & \\
Yes & 16.669 & $2.669-104.085$ & 0.003 \\
No & 1 & - & \\
History of Tuberculosis & & & \\
Yes & 6.497 & $1.061-39.794$ & 0.43 \\
No & 1 & - & \\
Number of sexual partners & & & 0.007 \\
$0-1$ & 1 & - & \\
$>1$ & 8.114 & $1.755-37.513$ & \\
\hline
\end{tabular}

Variables included in the model: age, marital status, history of STIs, history of herpes zoster, history of tuberculosis, number of sexual partners over the past 12 months, type of sexual partners.

\section{Discussion}

It is important to show limitations of this study about HIV seroprevalence and associated factors among new detainees. Indeed, given that it was a behavioral study, response biases may have occurred. In addition, for a better representativeness of the new prisoners, all newly incarcerated people at HJCA should be included in the study and not only those who presented themselves at the entrance of the prison. Despite these limitations, this study keeps its originality and found important factors which should be taken into account to control HIV infection in Ivory Coast.

In this study, $31.9 \%$ of respondents had multiple sexual partners. This percentage is close to proportions found in previous studies. Indeed, in 2002, a study conducted by Touré about STIs in Ivory Coast found that $40.1 \%$ of participants had multiple sexual partners [4]. Also, Adefuye [5] and Kalina [6] found in their studies respectively $40 \%$ and $27 \%$ of respondents (students) who had more than one sexual partners. Sexuality with multiple partners is a major risk factor of getting STIs and the risk increases with the number of partners. Indeed, each partner participates in the increase of the infection transmission risk [7]. Concerning condom use, only $49.4 \%$ of respondents, in our study, said they used it during sexual intercourse and $29.2 \%$ stated that they used condom during their last sexual intercourse. In Touré's [4] and Kalina's [6] studies, proportion of condom utilization during respondents' last sexual intercourse were $37.1 \%$ and $25.3 \%$ respectively. While condoms are now well recognized as an effective mean of protecting against HIV / AIDS and STIs, it is not always used in certain practices that are wrongly considered safe. According to Benoit $\mathrm{F}$, the use of the condom during 
intercourse needs to be studied taking into account the context of its use. Indeed, it is not the number or percentage of use that is the most important, but with which partner the condom is utilized [8]. In sum, the new inmates had risk behaviors identical to the general population. More than half of the respondents $(58.1 \%)$ were unaware of their HIV status at the time of their incarceration. However, knowledge of serological status would allow the early implementation of therapeutic or prophylactic interventions and would promote the adoption of prevention behaviors.

According to UNAIDS, many HIV-positive inmates have contracted the infection out of the prison. Many detainees come from communities where HIV prevalence is higher than the mean prevalence in the general population [9].

In this study, HIV seroprevalence among new inmates was $7.9 \%$. Considering the national seroprevalence which is $3.7 \%$ [10], it appears that new prisoners included in this study constitute a group at high risk of HIV infection. HIV prevalence found in this study is greater than the prevalence found by ESTHER in 2011 in the same prison (5.6\%) [3]. Simooya, in 2001, found HIV prevalence of $27 \%$ in Zambia three main prisons [11]. In Togo, a survey conducted between 2011 and 2012 among individuals incarcerated for more than three months showed a HIV prevalence of $4.3 \%$ [12]. A systematic review of HIV in prisons in low and middleincome countries found that HIV prevalence was greater than $10 \%$ in 20 out of 75 countries [13]. This serious problem of $\mathrm{HIV}$ in prison requires vigorous and effective measures.

In this study, findings showed that HIV infection was more prevalent among married detainees as compare to single inmates $(p=0.04)$. This situation could be explained by the fact that unprotected sex is not limited to the usual partner among married individuals. In addition, the high proportion of HIVpositive individuals among respondents who had sex with occasional partners compared to those who did not $(\mathrm{p}<0.001)$, and the great number of HIV-positive people among new detainees who had sex with more than one partner compared to those who did not $(\mathrm{p}<0.001)$ support our argumentation that married respondents did not limit unprotected sex to the usual partner, and point out that the risk of getting HIV increases with the number of sexual partners [9]. HIV was also prevalent among respondents aged 30 years and greater. This situation could be explained by a sexual hyperactivity with risky sexual practices of people in this age group.

In our study, history of herpes zoster, tuberculosis, and STIs were associated with HIV status. Previous studies also found an association between HIV status and these diseases [15-17]. STIs play a major role in the sexual transmission of HIV. In fact, STIs, especially ulcerative STIs create genital lesions that facilitate the penetration of HIV into the body. Similarly, HIV infection aggravates the clinical signs of STIs and complicates their treatment [18]. Concerning tuberculosis, HIV infection promotes the reactivation of a latent infection of mycobacterium tuberculosis, whereas mycobacterium tuberculosis promotes HIV replication and thus accelerates the natural course of HIV infection towards an immunosuppression [19]. Tuberculosis is the leading cause of opportunistic infections and deaths among people living with HIV in sub-Saharan Africa [13] and an HIV-infected person is at high risk of developing active tuberculosis in a country with a high incidence of tuberculosis [19]. Concerning shingles, it is a very frequent manifestation of HIV infection which can occur at all stages, but often it happens at a stage of severe immunosuppression [19].

\section{Conclusion}

This study revealed a high prevalence of HIV among new inmates, most of them having high-risk behaviors. These findings challenge us to reinforce the promotion of safer behaviors, the systematic screening of HIV among prisoners, both newer and older ones, and the treatment of HIV-positive individuals. To be more effective, all these measures should be associated with improvement of living conditions in prisons.

\section{References}

[1] Nations Unies (UN). Office contre la drogue et le crime. Le VIH/sida: Prévention, soins, traitement et soutien en milieu pénitentiaire. New York: UN; 2008. 56p.

[2] Weinbaum CM, Sabin KM, Santibanez SS. Hepatitis B, hepatitis C, and HIV in correctional populations: a review of epidemiology and prevention. AIDS. 2005; 19 Suppl 3: S41-6.

[3] ESTHER. Renforcement de la prise en charge des personnes vivant avec le VIH au sein de la maison d'arrêt et de correction d'Abidjan (MACA).

http://vih.org/sites/default/files/HJCA\%20\%202010.pdf, consulted on June $29^{\text {th }} 2009$.

[4] Touré B, Koffi NM, Gohou V, Aké O, Konan YE. Acceptabilité du dépistage du VIH chez les patients atteints d'infections sexuellement transmissibles au dispensaire antivénérien d'Adjamé, Côte d'Ivoire. Bull Soc Pathol Exot. 2006; 99 (4): 251-3.

[5] Adefuye SA, Abiona CT, Balogun AJ, Lukobo-Durrell M. HIV sexual risk behaviors and perception of risk among college students: implications for planning interventions. BMC Public Health. 2009; 9: 28.

[6] Kalina O, Geckova MA, Jarcuska P, Orosova O, et al. Psychological and behavioural factors associated with sexual risk behaviour among Slovak students. BMC Public Health. 2009; 9: 15.

[7] ONUSIDA: Intensification de la prévention du VIH/SIDA. Genève: ONUSIDA; 2006-2007. 22 p.

[8] Ferry B. Systèmes d'échanges sexuels et transmission du VIH/sida dans le contexte africain. Sciences sociales et sida en Afrique: Bilan et perspectives: communications. 1996: p 11328.

[9] ONUSIDA: Le sida dans les prisons, Avril 1997. 8 p. www.unaids.org/sites/default/files/media_asset/prisonspov_fr_0.pdf. Consulted on March 3rd 2104.

[10] République de Côte d'Ivoire, Ministère de la santé et de la lutte contre le sida: Enquête Démographique et de Santé à Indicateurs Multiples, Rapport préliminaire. 2012. 561p. 
[11] Simooya OO, Sanjobo NE, Kaetano L, Sijumbila G; Munkonze FH, Tailoka F et al. 'Behind walls': a study of HIV risk behaviours and seroprevalence in prisons in Zambia. AIDS. 2001; 15 (13): 1741-4.

[12] Programme National de Lutte contre le Sida et les IST du Togo. Enquête comportementale et de séroprévalence chez les prisonniers. 2011. $48 \mathrm{p}$.

[13] Dolan K, Kite B, Black E, Aceijas C, Stimson GV. HIV in prison in low-income and middle-income countries. Lancet Infect Dis. 2007; 7 (1): 32-41.

[14] Tiembre I, Dagnan S, Benié J, Ekra D, N'Doutabé M, Kouamé $\mathrm{K}$ et al. Séroprévalence du VIH au dispensaire Antivénérien de l'Institut National d'Hygiène Publique d'Abidjan. Bull Soc Pathol Exot. 2004; 97 (5): 334-5.

[15] Tiembre I, Ekra D, Bénié J, N'Guetta K, Attoh-Touré H, Koffi $\mathrm{K}$ et al. Séroprévalence de l'infection à $\mathrm{VIH} /$ sida dans un centre de conseil et dépistage volontaire périphérique d'Abidjan (Côte d'Ivoire). Med Afr Noire. 2009; 56 (12): 627 632 .
[16] Zinzendorf N, Eba TP, Guigui M-M, Gouati BT, Menan EI. Séroprévalence de l'infection à VIH/sida chez les volontaires de l'armée nouvelle de Côte d'Ivoire. Cah Santé Publique. 2011; 10 (2): 155-161.

[17] Mbopi-Keou FX, Monthe Nkala IV, Kalla GCM, NguefackTsague G, Kamga GH, Noubom M. Séroprévalence et facteurs associés au VIH et aux hépatites virales $B$ et $\mathrm{C}$ dans la ville de Bafoussam au Cameroun. Pan Afr Med J. 2015; 20: 156. doi: 10.11604/pamj.2015.20.156.4571.

[18] Lando MJ, Mboua JN, Tardy M, Noumsi N, Nzeuseu V, Kouanfack C. et al. Affections cutaneo-muqueuses au cours de l'infection à VIH/SIDA, $19 \mathrm{p}$.

[19] http://www.gfmer.ch/Medical education En/Cameroon/Pdf/A FFECTIONS_CUTANEES.pdf Consulted on March 2014.

[20] Dagnra Y, Adjoh K, Tchaptchet Heunda S. Prévalence de la co-infection VIH-tuberculose et impact de l'infection VIH sur l'évolution de la tuberculose pulmonaire au Togo. Bull soc pathol exot. 2011; 104 (5): 342-5. 